\title{
Linking Core Competence, Innovation and Firm Performance
}

\author{
Öznur GÖKKAYA \\ Kocaeli Üniversitesi, Hereke Meslek \\ Yüksekokulu, 41750 Hereke Körfez - \\ Kocaeli, Türkiye \\ gokkayaoznur@gmail.com
}

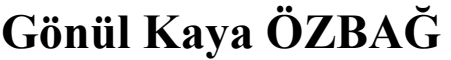 \\ Kocaeli Üniversitesi, Yıldız Bilge \\ Barbaros Denizcilik MeslekYüksekokulu, \\ 41500 Karamürsel - Kocaeli, Türkiye \\ gonul.kaya1@kocaeli.edu.tr
}

\begin{abstract}
Organizational resources and capabilities realized by business practitioners and researchers have significant importance as they support firm performance and competitive advantage. However, what exactly core competence is not clearly understood since terms such as resource, capability and competence are used interchangeably by researchers. From this point forth, this article provides a framework for separating organization's core competencies from resource and capability. We propose three empirical determiners such as uniqueness, inimitability and extendibility to the research model for separating organization's core competencies from resource and capability. Second, the proposed core competence framework serves as a tool for assessing the relationship between core competencies and innovation. Finally, the paper intended to help leaders and managers about how they can enhance firm performance by means of supporting core competencies and innovation.
\end{abstract}

Keywords: Core Competence, Innovation, Performance

\section{Introduction}

Since innovation is so crucial in sustaining competitive advantage, many studies have investigated the innovation process (Maidque, 1980; Damanpour, 1988; Zirger and Maidique 1990; Dougherty and Hardy, 1996). Although there are number of innovation models, few have examined the relationship between innovation and core competence. The majority of studies have examined the significant effects of competences on firm performance or competitive advantage (Wernerfelt, 1984; Hitt and Ireland,1983; Barney, 1991; Rumelt, 1991; Amit ve Schoemaker, 1993; Peteraf, 1993; Hafeez et al., 2002). So, it seems that there is a need in the literature on measuring the impact of core competence on innovation. We believe that since innovation and also core competence is complex subjects and characterized by low levels of understanding, the more emprically examined it in different industries and countries, the more easily it can be understood and applied by managers in organizations.

To survive and succeed, firms must innovate. Intensified global competition and an emphasis on rapidly changing technogies have only reinforced this long-held notion. To remain competitive, firms must develop and introduce new products or services to 
external markets (Cummings\& Oldham, 1997: 22). According to Zamora et al. (2006, p.225) innovative companies must adjust their intrinsic and extrinsic functions to respond to the demands of the environment and thus maintain and improve business performance. Companies struggling to maintain an innovative advantage perceive and attract new opportunities that might grant them efficiency and effectiveness.

The previous empirical studies of organizational innovation have shown that there is a positive and direct relationship between innovation and firm performance (Hult et al., 2004; Kleinschmidt, Cooper , Elko, 2000; Erdil et al., 2004; Lin \& Chen, 2007; Rubera and Kirca 2012). Regular product introductions can satisfy customer needs, generate profits, and enhance long term competitiveness as well as the firm's ability to differentiate itself from the competition (Zahra, 1996, p.297). Based on this view, this research attempts to determine key antecedents of core competence and integrates them into a conceptual framework relating core competence, firm innovativeness and firm performance. In other words, we handle the firm innovativeness as a result of core competence and try to examine the link between core competence and firm innovativeness with the ultimate goal of improving performance.

\section{Core Competence}

The core competence concept, evolved from the resource based view and sometimes called by different names such as organizational competencies, distinctive capabilities or dynamic capabilities, has been widely studied by researchers (Selznick 1957; Andrews, 1971; Barney 1986; Dierickx and Cool 1989; Itami and Numagami, 1992; Teece et al, 1997 ) especially since the publication of Prahalad and Hamel's (1990) well-known article, "The Core Competence of the Corporation." Although studied widely by the researchers, there isn't an agreement among them in a standard definition of core competence since it is an umbrella term which covers resources and capabilities. However, it is possible to find some key determiners in the literature that researchers emphasize in describing the core competencies. For instance, Mooney defines core competence as a capability that is central to a firm's value generating activities instead of only ownership of a resource (2007, p.112). Pitt and Clarke define core competence as assets and skills that are knowledge based, distinctive, firm specific and difficult to imitate and they added that they can be formed by using the tangible and intangible value genarating assets and resources (1999, p.302).

Hamel and Prahalad, suggests the term core competence and defined it as " the collective learning in the organization, especially how to coordinate diverse production skills and integrate multiple streams of technologies" (Hamel and Prahalad, 1994: 1999). These collective learning or coordination skills behind the firm's product lines are the source of its competitive advantage and enable the firm to introduce a new array of products and services. By focusing on their core competencies, firms get competitive advantage since they do those things at which they are the best (Srivastava, 2005, p.51).

Organizations have many competencies and capabilities, however only a few of them are combined and integrated in such way that they can be considered core competences. So if a business manager mentions 40-50 core competencies of a medium-sized enterprise, he probably refers to capabilities rather than core competencies (Hamel and Prahalad, 1996, p.262) An other important point is that if the competencies do not create products or services that are exceptionally different or if they are imitated easily they are most probably not core. Some assume that core 
competencies are the backbones of competitive advantage which change more slowly than products and markets (Hamel and Prahalad 1990; Hafeez et al.;2002, Gupta et al.; 2009)

Since the concept is not conceived easily, Hamel and Prahalad suggest three criteria that distinguishes a core competence from a competence; a core competence must contribute significantly to customer benefit from a product, a core competence should be competitively unique, must be difficult for competitors to imitate and finally , a core competence should provide potential access to a wide variety of markets (Prahalad and Hamel, 1990; Hamel and Prahalad, 1994). Similarly, according to Kak, a capability must meet three terms to be estimated as a core competence; customer value, competitor differentiation and extendibility (Kak, 2002; 1).

Accordingly, in this paper, a competence satisfies the above three criteria is taken as a core competence. Competitively uniqueness refers to the range to which a capability is distinctive among competitors (Hafeez, 2007: 3595). Capabilities possessed by many firms or can be imitated easily are doubtfully to be a source of competitive advantage. The durability of a firm's competitive advantage is partly a function of how successfully other firms are able to imitate the focal firm's technological competence. Valuable capabilities make possible to develop and implement strategies that create value for customers (Thompson and Strickland, 1999: 99). Hamel and Prahalad suggest that customers are the final judge of whether something is a core competence or not (1994: 225). Finally, a core competence should give permission to the firm to enter new markets and products developed from this core competence could be used to a larger extent in the company (Ljungquist, 2007: 241).

In conclusion, capabilities are formed by the integration of resources whereas core competencies are formed by the integration of capabilities. Core competencies are firm specific, built up over time and not subject the sudden change. They should be identified with the objective in mind to bring the greatest value to the end customer. In order to mention core competences a firm should have unique resources. Having unique resources is the first step, unless they are performed repeatedly and effectively to create customer value, competitive advantage over others will be very difficult. The highly important step is to integrate these unique resources and capabilities among all parts of the corporation effectively. Therefore, the combination of above criteria is an important means of developing core competences.

\section{Linking Core Competence and Innovation}

Many researchers have emphasized the relationship between competences and innovation and asserts that a firm's core competences enhances its ability to innovate. For instance, Zirger and Maidique who are famous for their efforts on innovation research tried to determine the key factors that affect product innovation. According to this researh findings, two of the five most important factors affecting product innovations are the product's value to the customer and the synergy of the new product with the firm's existing competences (Zirger and Maidique, 1990: 867). There are many researches which suggest that innovations with a closer fit to firm competences tended to be more succesful (Cooper and De Brentani, 1991; Cooper and Kleinschmidt, 1993; Kleinschmidt and Cooper, 1991; Song ve Parry, 1997a; 1997b; Zirger ve Maidique, 1990). Existing competences may be used as leverage points to add new competences, which is indeed having low risk and utilizing slack resource. 
Since this creates opportunities with low conflicts, Hamel and Prahalad (1994) suggested leveraging core competences, too. They argued that in order to leverage core competences, managers need to avoid a product-centric view of their firm and examine the capabilities on which their main products are established on. According to Hamel and Prahalad (1994: 227) ' . . in defining core competencies, managers must work very hard to abstract away from the particular product configuration in which the competence is currently embedded, and imagine how the competence might be applied in new product areas.' They claimed (1994: 227) that one product may comprise several competences, and one competence may create different products. Despite this potential and useful interchange, competences are not fully utilized by organizations and not all possible value is extracted from them.

Knowledge-based theory emphasizes that most innovations are incremental in nature, building on already existing knowledge and capabilities of firms. In general, innovations are the result of new combinations of existing knowledge and incremental learning as Schumpeter (1968) claimed. Firms like individuals may acquire and apply the external knowledge relevant to their prior knowledge. A firm is better able to recognize and exploit new information relevant to an existing firm knowledge. This valuable experience provides the firm with the background necessary both to recognize the value of and implement new methods or processes since the growth of knowledge is experiential. Therefore, a firm's absorptive capacity, the learning that occurs through absorption of external knowledge is a critical concept in understanding competence building and innovation (Cohen \& Levinthal, 1990; Kogut \& Zander, 1992; Pitt and Clarke).

On the other hand, the scenerio can be reversed, what Leonard-Barton (1992) calls "core rigidities." Core rigidities may result from the institutionalization of knowledge and routines in a way that new approaches and information are not supported that leads to a gap between current environmental requirements and a corporation's core capabilities. Yet, accumulated firm knowledge is the most superior ingredient in competence development and innovation, firms may exaggerate the value of their competencies and try to develop solutions with inappropriate sets of knowledge. In conclusion, innovations with a closer fit to firm core competences tended to be more succesful unless these core competences become core rigidities Existing competences may be used as leverage points to add new competences, which is indeed having low risk and utilizing slack resource.

\section{Linking Innovation and Firm Performance}

Gopalakrishnan and Damanpour defined innovation as "programs, policies, systems, equipment, service, product, behavior or idea which is newly adapted to organization" (Shanthi and Fariborz, 2000: 15). According to Hult et al. (2004) innovation is the capacity to introduce of some new process, product, or idea in the organization. Similarly, Roehrich, (2004) defined innovativeness as the capability of a firm to develop new product solutions at a fast rate within a specific time period. On the other hand, innovation is a multidimensional construct involving several aspects such as product, process, adminstration, market, technological and strategic planning (Wang and Ahmed, 2004; Hurley and Hult, 1998; Maravelakis et al, 2006; Lin and Chen, 2007). 
The previous empirical studies of organizational innovation have shown that there is a positive and direct relationship between innovation and firm performance (Hult et al., 2004; Kleinschmidt, Cooper , Elko, 2000; Erdil et al., 2004; Lin \& Chen, 2007; Rubera and Kirca 2012). For instance, Rubera and Kirca's (2012) research findings suggest that innovativeness has direct positive effects on financial position and firm value and it indirectly affects firm value through its effects on market position and financial position. An other study by Hurley and Hult (1998) that investigated the relationships among organizational innovation, market orientation, and organizational learning and showed that all these issues cooperatively influenced the level of performance.

In the large body of literature, new product introduction is associated with an increase in sales, market shares and firm growth because it significantly contributes to the satisfaction of existing customers as well as attracting new customers (e.g. Wang and Wei, 2005; Bayus, Erickson, and Jacobson, 2003; Tung, 2012 ). Product innovation also increases the capacity of a firm to adapt to a constantly changing environment and increases a firm's leverage in a highly competitive market (Tung, 2012, p.95 ). A striking study including 90,000 enterprises in 16 European countries realized by Hashi \& Stojcic (2013) revealed that investment in innovation activities positively influences the innovation output measured by the proportion of sales attributable to new products which in turn contributes to the better productivity of firms. Therefore, it's wise to say that a firm's performance is muchly dependent on product innovation since it stimulates its market share as well as its capacity to cope with competitive market conditions by diversifying products that other firms are lacking to create.

Relatedly, Gunday and his collegues (2011) examined innovativeness, in the Turkish manufacturing industry, drawing on a sample of 184 manufacturing firms. Their findings support the fact that innovation strategy is a major driver of firm performance and should be developed and carried out as an essential part of the business strategy. An other study by Sookaneknun and Ussahawanitchakit (2012) focused on the effect of transformational leadership affecting organizational innovation capability which in turn influence firm performance confirmed that organizational innovation capability had a positive effect on firm performance.

In conclusion, the literature provides several explanations why innovation may stimulate firm performance. First, studies indicate that innovation leads to improved quality of products and services. Second, it reduces the cost of inputs by establishing cheaper raw materials and processes. For example, firms that use innovative energy saving production processes are able to lower the cost of production of the same output that could be attained at a higher energy cost. Third, it allows product differentiation giving consumers an array of products to choose from. Morover, it increases flexibility in production and service delivery that is paramount to the success of business. Lastly, it increases efficiency in production that allows the firm to apply resources precisely to produce the exact output. Maybe more importantly, innovation which are created by individuals' non-codified body of expertise and skills accumulated through experience and so are highly rare and difficult for competitors to imitate (Wei and Lou, 2005: 1902). In sum, the vast majority of previous researches agree that innovation is critical to achieving a competitive advantage and firm performance (Hult, Hurley and Knight, 
2004; Han et al., 1998; Kleinschmidt, Cooper, Elko, 2000; Lin \& Chen, 2007; Rubera and Kirca's 2012). Thus, consistent with the previous literature we expect a positive relationship between innovation and firm performance

\section{Conceptual Framework and Hypotheses Development}

This paper suggests core competence to be significant determinant of innovation and hypothesize core competence as a multi-dimensional construct consisting of three dimensions: uniqueness, customer value, and extendibility. We also propose that a positive correlation exists between innovation and firm performance. The proposed conceptual model guiding this research is depicted in Figure 1.

\section{Fig.1 Research Model}

\section{Core Competence}

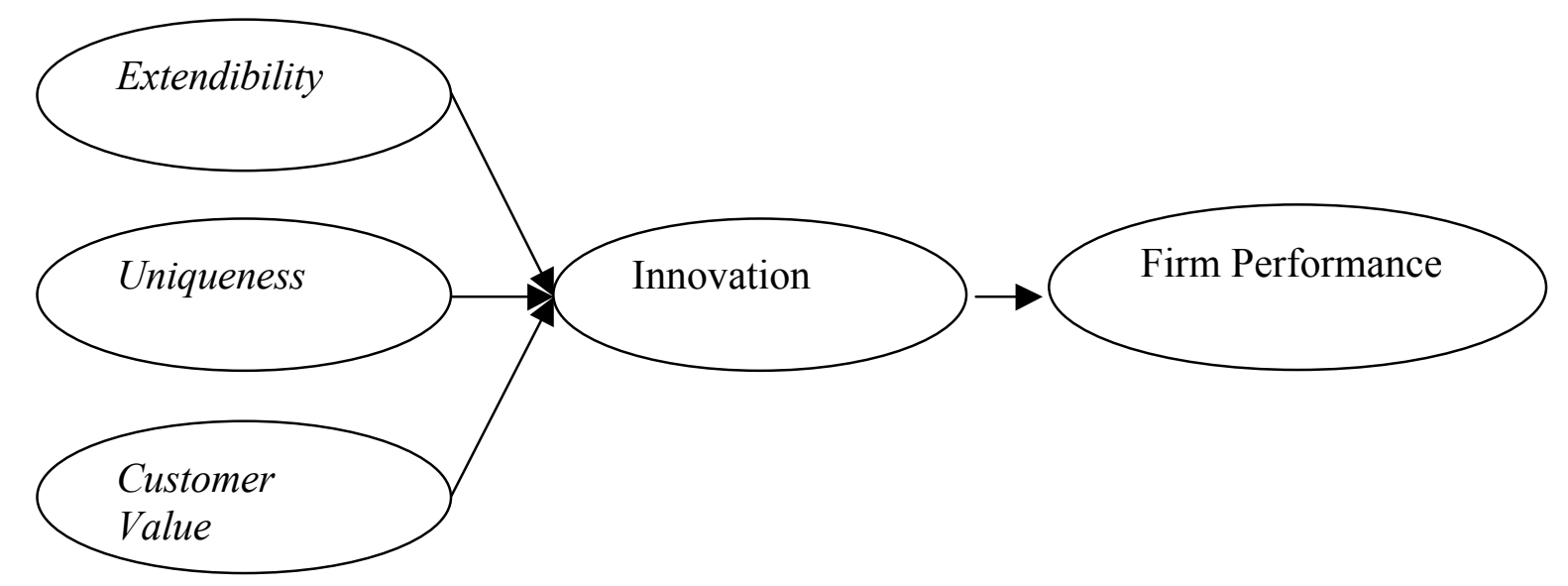

Consequently, to examine these relationships we developed four research hypotheses:

H1: A positive correlation exists between uniqueness and innovation

$\mathrm{H} 2$ : A positive correlation exists between customer value and innovation.

H3: A positive correlation exists between extendibility and innovation

H4: A positive correlation exists between innovation and firm performance.

\section{Methodology}

\section{Research Goal}

The primary aim of this study is to measure the impact of core competencies on innovation. This article doesn't provide a framework for describing and evaluating an organization's core competencies since the difficulty of focusing on different core competencies of firms that operate in more than one sector. We mainly try to answer if core competencies boost innovation and also if innovation boost firm performance. 


\section{Scale and Measurement}

In order to empirically investigate the hypotheses, firms operating in Kocaeli were surveyed. Using the documents of Kocaeli Chamber of Commerce, 250 firms among 518 are identified as the target group of the research because of their availableness. Tools such as e-mail, letter and face to face interviews are used for gathering data from the managers. A total of 138 questionnaires among 86 firms has returned. Of the participants, $\% 62$ are married, $\% 53$ have university educations and $\% 8$ have master education.

To test the above hypotheses, multi-item scales adopted from prior studies for the measurement of constructs were used. There are 12 questions in core competencies scale that are developed from the study of Hamel and Prahalad (1994) and they are including three dimensions named as uniqueness, customer value, and extendibility. On the other hand, innovation was measured by 10-items developed from the studies of Hansen and Birkinshaw (2007) and Hult et al. (2004). Firm performance was measured by 9 items adopted from the studies Fuentes, Saez, Montes's (2004) and Kaynak's (2003). All items were rated using a 5-point scale ranging from 1 ("Very strongly disagree") to 5 ("Very strongly agree").

\section{Analysis and results}

We used the partial least squares (PLS-Graph 3.0, Chin, 2001) approach to path modeling to estimate the measurement and structural parameters in our structural equation model (SEM) (Chin, 1998). The reason for using this technique is that PLS method can operate under limited number of observations and more discrete or continious variables. Therefore PLS method is an appropriate method for analysing operational applications. PLS is also a latent variable modeling technique that incorporates multiple dependent constructs and explicitly recognizes measurement error (Karimi, 2009). Also PLS is far less restrictive in its distributional assumption and PLS applies to situations where knowledge about the distribution of the latent variables is limited and requires the estimates to be more closely tied to the data compared to covariance structure analysis (Fornell and Cha, 1994).

\section{Measurement validation}

In this study, following Kleijnen, Ruyter and Wetzels (2007), we used reflective indicators for all our constructs (see, Appendix 1). To assess the psychometric properties of the measurement instruments, we estimated a null model with no structural relationships. We evaluated reliability by means of composite scale reliability $(\mathrm{CR})$ and average variance extracted (AVE). For all measures, PLS-based CR is well above the cut-off value of .70, and AVE exceeds the .50 cut-off value. In addition, we evaluated convergent validity by inspecting the standardized loadings of the measures on their respective constructs and found that all measures exhibit standardized loadings that exceed .60. We next assessed the discriminant validity of the measures. As suggested by Fornell and Larcker (1981), the AVE for each construct was greater than the squared latent factor correlations between pairs of constructs (see Table 1). 


\section{Hypothesis testing}

According to the correlation results seen in Tablo 2, there is a positive significant result among all dimensions of core competence and innovation and also between innovation and firm performance.

Table 2. Correlations of latent variables

\begin{tabular}{|l|c|c|c|c|c|}
\hline Variables & 1 & 2 & 3 & 4 & 5 \\
\hline 1.Uniqueness & 1 & $.546^{* *}$ & $.639^{* *}$ & $.364^{* *}$ & $.444^{* *}$ \\
\hline 2.Extendibility & & 1 & $.629^{* *}$ & $.472^{* *}$ & $.355^{* *}$ \\
\hline 3.Customer Value & & & 1 & $.654^{* *}$ & $.425^{* *}$ \\
\hline 4.Innovation & & & & 1 & $.562^{* *}$ \\
\hline 5.Firm performance & & & & & 1 \\
\hline
\end{tabular}

As shown in Table 3, the results illustrate that our hypotheses are confirmed. The results indicate that uniqueness positively affects innovation $(\beta=.26, \mathrm{p}<.05)$, customer value positively affects innovation $(\beta=.54, \mathrm{p}<.01)$, extendibility positively affects innovation $(\beta=.47, p<.01)$. Therefore $\mathrm{H} 1, \mathrm{H} 2, \mathrm{H} 3$ are supported. With regard to effects of innovation on firm performance, we found that innovation positively affects firm performance in a very high rate $(\beta=.49, \mathrm{p}<.01)$. Therefore $\mathrm{H} 4$ is also supported.

Table 3 Hypothesis Testing Results

\begin{tabular}{clcc}
\hline Hypothesis & Relationship & $\begin{array}{c}\text { Path coefficient } \\
(\boldsymbol{\beta})\end{array}$ & Results \\
& & $.26^{*}$ & Supported \\
\hline $\mathrm{H} 1$ & uniqueness $\rightarrow$ innovation & $.54^{* *}$ & Supported \\
\hline $\mathrm{H} 2$ & customer value $\rightarrow$ innovation & $.47^{* *}$ & Supported \\
\hline $\mathrm{H} 3$ & extendibility $\rightarrow$ innovation & $.49^{* *}$ & Supported \\
\hline H4 & innovation $\rightarrow$ firm performance & & Final model \\
\hline$R^{2}$ & Endogenous construct & & .37 \\
& innovation & & .28
\end{tabular}

Path coefficients are not standardized. ${ }^{* *} p<.01,{ }^{*} p<.05$ 


\section{Conclusion}

The business competitive environment is getting tougher by limited resources, local and global competition, fast and intensive technological change. Innovation by adding value to the company increases the chance of passing ahead of the competition.. For that reason, managers and scholars have been very interested in understanding the innovation process in organizations.

This study provides initial empirical evidence of the relationship between core competences, innovation and firm performance. The findings of the many researches show that core competences have positive impacts on innovation and its success (Cooper and De Brentani, 1991; Cooper and Kleinschmidt, 1993; Kleinschmidt and Cooper, 1991; Song ve Parry, 1997a; 1997b; Zirger ve Maidique, 1990). Similarly, in this study, it is found that core competences have a positive and significant effect on innovation. Therefore, generating and maintaining a good fit between core competences and new product development is critic on the success of innovation.

Research results indicated that all three dimensions of core competence; uniqueness, extendibility and customer value; are significant in explaining innovation. Therefore, to remain competitive, managers can try to enhance innovation by managing each dimension of core competence; uniqueness, extendibility and customer value. Maybe it would be more practical to choose one sector since core competences are frequently discussed for one or a few individual companies in which firm-specific lists of competences are generated that might be relevant in the context of each individual case (Hamel \& Heene, 1994). However, a wider group of general indicators of core competences seems necessary to improve our understanding of the role that core competences play in innovation process. On the other hand, it would be beneficial for a future study to investigate the impact of firm-specific competences on innovation, organizational performance or competitive advantage.

An other finding of this study is that innovation has significant effects on firm performance. The company's efforts in developing new products and processes improve the performance of the organization including qualitative and quantitative performance. The literature review reveals that in line with our findings there are some studies which confirm the positive relationship between new product innovation and firm performance such as business sales ratio, market share and growth (e.g. Wang and Wei, 2005; Bayus, Erickson, and Jacobson, 2003 ; Tung, 2012). This result suggests that the capability of the organization in introducing of some new process, product, or idea stimulates market share as well as its capacity to cope with competitive market conditions which leads to a conclusion that a firm's performance is muchly dependent on firm innovativeness.

This study leads us to the conclusion that for stimulating innovation firms need to think about their core competences. However, while, performing the questionnaire survey on firms to prove our hypothesized research model, we see that managers are not fairly clear about the meaning of core competence. More emprical research is needed to increase awareness of managers and scholars about core competences that can boost innovation. Although it is not a simple task, the firms should determine carefully their core competences by considering our suggested determiners; uniqueness, extendibility and customer value and manage them leading to innovation that have important effects on firm performance. 
Ö. Gökkaya - Ö. K. Özbağ 7/1 (2015) 90-102

\section{REFERENCES}

Andrews, K. (1971). The conceptof corporate strategy. Homewood, III.: Dow Joneslrwin.

Amit Raphael and Schoemaker J. Paul (1993). Strategic Assets and Organizational Rent. Strategic Management Journal, V:14, No:1

Alegrea Joaquin ve Chivab Ricardo (2008). Assessing the impact of organizational learning capability on product innovation performance: An empirical test, Technovation, 28.

Aron O'Cass and Phyra Sok (2012). Examining the role of within functional area resource-capability complementarity in achieving customer and product-based performance outcomes, Journal of Strategic Marketing, Vol. 20, No. 4, July 2012, 345-363.

Barney Jay (1991). Firm Resources and Sustained Competitive Advantage, Journal Of Management, Vol. 17,No 1, 99-120.

Barney, J. B. (1986). Types of Competetion and The Theory of Strategy: Toward an Intergrative Framework, Academy of Management Review, 11.

Bruce Kogut And Udo Zander (1992). Knowledge of The Firm, Combinative Capabilities, and The Replication of Technology, Organization Science, Vol. 3, No. 3, August.

Cummings, A., \& Oldham, G. R., (1997), EnhancingCreativity: Managing Work Contexts For The High Eotential Employee, California Management Review, 40: $22-38$.

Cohen M.Wesley ve Levinthal A. Daniel (1990). Absorptive Capacity: A New Perspective on Learning and Innovation, Administrative Science Quarterly, C:35, No:1, March.

Collis David ve Montgomery A. Cynthia (1995). Competing On Resources: Strategy In The 1990s, Harvard Business Review, July-August.

Cooper, Robert G.; De Brentani, Ulricke (1991). New Industrial Financial Services: What Distinguishes the Winners, Journal of Product Innovation Management, 8(2) June.

Cooper, Robert G.; Kleinschmidt, Elko J. (1993). Stage Gate Systems for New Product Success, Marketing Management, 1(4).

Kleinschmidt, E. J.; Cooper, R. G. (1991). The Impact of Product Innovativeness on Performance, Journal of Product Innovation Management, Dec, Vol. 8 Issue 4, p240-251.

Christensen, Clayton M.; Raynor, Michael E.; Anthony, Scott D. (2003). Six Keys to Creating New Growth Business, Harvard Management Update, Jan. 8(1).

Damanpour Fariborz et al. (1988). The Relationship Between Types of Innovation and Organizational Performance, Journal of Management Studies, 26(6). 
Ö. Gökkaya - Ö. K. Özbağ 7/1 (2015) 90-102

Diericks, I., Cool, K., \& Barney, J.B. (1989), Asset Stock Accumulation and Sustainability of Competitive Advantage, Management Science, 35(12).

Dougherty Deborah ve Hardy Cynthia (1996). Sustained Product Innovation In Large, Mature Organizations: Overcoming Innovation-to-Organization Problems, The Academy of Management Journal, 39/5.

Erdil, S., Erdil, O. and Keskin, H., (2004), The relationships between market orientation, firm İnnovativeness and innovation performance, Journal of Global Business andTechnology, 1(1), 1-11.

Grant M.Robert, 1991. The Resource-Based Theory Of Competitive Advantage: Implication For Strategy Formulation, California Management Review, Spring.

Gupta Samir, Woodside Arch, Dubelaara Chris, Bradmore Don (2009). Diffusing Knowledge-Based Core Competencies For Leveraging Innovation Strategies: Modelling Outsourcing To Knowledge Process Organizations (KPOs) in pharmaceutical networks, Industrial Marketing Management, 38 (2), February, pp. 219-227.

Hafeez K., Zhang Y. ve Malak N. (2002). Core Capabilities for Sustainable Competitive Advantage: A Structured Methodology for Identifying Core Capabilities, IEEE Transactions on Engineering Management, 49-1.

Hafeez Khalid Hafeez ve Essmail Ali, 2007. Evaluating Organisation Core Competences And Associated Personal Competencies Using Analytical Hierarchy Process, Management Research News, (30)8.

Hafeez K., Zhang Y. ve Malak N. (2002). Core Capabilities for Sustainable Competitive Advantage: A Structured Methodology for Identifying Core Capabilities, IEEE Transactions on Engineering Management, 49-1.

Hafeez K., Zhang Y. ve Malak N. (2007). Outsourcing non-core assets and competences of a firm using analytic hierarchy process,December, 34(12),pp. 3592-3608

Hamel Gary and Prahalad C.K. July-1994. Competing For The Future, Harvard Business School Press Books.

Hansen T. Morten ve Birkinshaw Julian, The Innovation Value Chain, Harvard Business Review, Haziran, 2007.

Hitt A. Michael, Ireland R. Duane, Keats W. Barbara ve Vianna Antonio (1983). Measuring Subunit Effectiveness, Decision Sciences, V:14, No:1.

Helfat Constance E. and Peteraf Margaret A. (2003). The Dynamic Resource-Based View: Capability Lifecycles, Strategic Management Journal, Volume 24, Issue 10, pp.889-1068

Hult, G. T. M.,Hurley, R. F., \& Knight, G.A. (2004). Innovativeness: Its Antecedents and Impact on Business

Performance, Industrial Marketing Management, 33, 429-438.

Hurley, R. F.Hult GTM. Innovation, Market Orientation, and Organizational Learning: An Integration and Empirical Examination, J. Mark 1998,62:42-54. 
Ö. Gökkaya - Ö. K. Özbağ 7/1 (2015) 90-102

Itami, Hirovuki; Numagami, Tsuyoshi (1992). Dynamic Interaction Between Strategy and Technology, Strategic Management Journal, Special Issue, Vol. 13

Kak Anjana, 2002. Sustainable Competitive Advantage with Core Competence, A review, Global Journal of Flexible Systems Management, 3(4).

Leifer R., McDermott, C., O’Connor, G., Peters, L., Rice, M, \& Veryzer, R. 2000. Radical Innovation: How Mature Companies Can Outsmart Upstarts, Boston: Harvard Press.

Leonard-Barton Dorothy, Core Capabilities, Core Rigidities: A Paradox In Managing New Product Development, Strategic Management Journal, Yaz Özel Say1, 13, 1992.

Ljungquist Urban, 2007. Core Competence Beyond Identification: Presentation Of A Model, Management Decision, 45(3).

Maidque, M.A. 1980. Entrepreneurs, Champions \& Technological Innovation, Sloan Management Review, 2(59).

Miller, Danny; Eisenstat, Russell; Foote, Nathaniel. (Spring-2002). Strategy From The Inside Out: Building Capability-Creating Organizations.California Management Review. 44 (3).

Martyn Pitt \& Ken Clarke (1999). Competing on Competence:A Knowledge Perspective on the Management of Strategic Innovation, Technology Analysis \& Strategic Management, Vol. 11, No. 3.

Maravelakis, E., N. Bilalis, A. Antoniadis, K. A. Jones and V. Moustakis., (2006), Measuring and Benchmarking The Innovativeness Of SMEs: A ThreeDimensional Fuzzy Logic Approach, Production Planning and Control, Vol. 17(3), 283-292.

Money Ann (2007). Core Competence, Distinctive Competence, and Competitive Advantage: What Is The Difference?, Journal Of Education For Business, V:83 $\mathrm{N}: 2$

Nanda, A. (1996) Resources, capabilities and competencies. In Organizational Learning and Competitive Advantage, eds B. Moingeon and A. Edmondson. Sage, London. Nov-Dec, p110-115.

Peteraf, M. A. (1993). The cornerstones of competitive advantage: A resource-based view. Strategic Management Journal, 14, 179-192.

Prahalad C.K. and Hamel Gary (1990). The Core Competence Of The Corporation, Harvard Business Review, May-June.

Prajogo Daniel ve Ahmed Pervaiz K., Relationships Between Innovation Stimulus, Innovation Capacity, And Innovation Performance, R\&D Management. V:36, $\mathrm{N}: 5,2006$

Rumelt P. Richard (1991). How much does industry matter?, Strategic Management Journal, 12(3), pp.167-185.

Rubera, Gaia and Kirca Ahmet H, (2012), "Firm Innovativeness and Its Performance Outcomes: A Meta-Analytic Review and Theoretical Integration," Journal of Marketing, 76(3): 130-147. 


$$
\text { Ö. Gökkaya - Ö. K. Özbağ 7/1 (2015) 90-102 }
$$

Selznick, P.1957. Leadership and Administration, New York, Harper and Row.

Shanthi Gopalakrishnan and Damanpour, F. (2000), The impact of organizational context on innovation adoption in commercial banks, Engineering Management, IEEE Transactions, Feb., Volume: 47 , Issue: 1, p $14-25$.

Schumpeter, J.A. (1968). The Theory of Economic Development, Harvard University Press, Cambridge, MA.

Snow , C.C. \& Hrebiniak, L. G. 1980. Strategy,Distinctive Competence and Organizational Performance, Administrative Science Quarterly, 25.

Sookaneknun Santiparp and Ussahawanitchakit Phapruke (2012), Transformational Leadership, Organızational Innovation Capability, and Firm Performance of Cosmetic Businesses in Thailand, Journal of International Business and Economics, Volume 12, Number 4, 77-90.

Song, X. Michael; Parry, Mark E. Sep97. Teamwork Barriers in Japanese HighTechnology Firms: The Sociocultural Differences Between R\&D and Marketing Managers, Journal of Product Innovation Management, 14(5)

Srivastava C. Shirish (2005). Managing Core Competence of The Organization, Vikalpa, October - December, V:30, No:4

Teece D.J., Pisano G., ve Shuen A., Dynamic Capabilities and Strategic Management, Strategic Management Journal, C:18, No:7, 1997.

Thompson Arthur A., Strickland A. Alonzo, Strategic Management: Concepts and Cases, McGraw-Hill Comp. Inc., 11. Edt., Singapure, 1999.

Zahra, S.A.,(1996), Governance, Ownership, and Corporate Entrepreneurship: The Moderating Impact Of Industry Technological Opportunities, Academy of Management Journal, 39(6), 1713-1735.

Zirger B. J. ve Maidique M. A. 1990. A Model of New Product Development: An Empirical Test, Management Science, 36(7).

Wang, C.L. \& Ahmed P.K., (2004), 'The Development and Validation Of The Organisationa 1Innovativeness Construct Using Confirmatory FactorAnalysis', European Journal of Innovation Management, 7(4), 303-313.

Wernerfelt, Birger (1984). A Resource Based View of The Firm, Strategic Management Journal, Vol. 5 Issue 2.

Wolfe R. 1994. Innovation Review, Critique and Suggestesd Research Directions, Journal of Management Studies, 3(3). 